\title{
The Craft of Relief Carving Art and Its Impact on The 21st Century Jepara Craftsmen's Economic Life
}

\author{
Alamsyah $^{1^{*}}$, Arido Laksono ${ }^{2}$ \\ ${ }^{1}$ Department of History, Diponegoro University, Semarang - Indonesia \\ ${ }^{2}$ Department of English, Diponegoro University, Semarang - Indonesia
}

\begin{abstract}
The article on "The Craft of Relief Carving Relief Art and Its Impact on the 21st Century Jepara Craftsmen's Economic Life"describes the craft of relief carving which has an impact on the economic life of the Jepara craftsmen. The existence of Jepara relief art had been proven historiographical. Relief art has existed since the time of Queen Kalinyamat in the 16th century. The artifacts of relief carving art in Queen Kalinyamat's period are found in Mantingan Mosque in Jepara. The relief of carving craft gets its influences from various fields, including the influence of religion, local culture, Chinese culture, and others. In the 1990s to the beginning of the 21st century, relief craft increasingly innovated by enriching motifs and decorative reliefs in the form of flora, fauna and other motifs. Through various motives in the relief craft, the craftsmen get economic impact in the form of job sustainability.
\end{abstract}

Keywords: carving art; Relief; craftsmen; economy

\section{A. Introduction}

Jepara Regency is known as a region that produces carving arts. These handcraft products have been exported to various countries [1]. In Jepara, the centres of this carving furniture are spread throughout most of the Jepara region. The use of wood as the main material for carving has also brought serious issue. The article attempts to convey not only economic matter but also the issue on low carbon use. The craftsmen and the people involved in the process of carving should be aware of the importance of the sustainability of good environment by reducing the effect of carbon and conducting reforestation program in the surrounding areas.

In Jepara there are a number of Small Medium Industries (IMK/Industri Menengah Kecil) including wood crafts and wooden furniture. The number of IMK wood furniture is 5,993 units, while the IMK woodcraft is 1,522 units. This industry is an industry that converts basic goods by mechanism, chemistry or by hand so that they become finished product, semi-finished product, and/or products that are less valuable becoming higher value products. The wood furniture industry absorbs as many as 77,187 workers. The wooden handicraft industry absorbs 9,984 laborers [2]. One of the wood carving products is the relief. Relief is a sculpture that displays different shapes and images from the flat surface around it. Relief is a form of sculpture and 3dimensional carving [3], which in this context is made on a wooden surface.
This relief craft is found in several carving centres, including in Senenan Village, Tahunan Subdistrict, around the Jepara city and in the carving craft centre in Mulyoharjo. In Senenan Village, there are makers and craftsmen of relief carvings. Since around the 1970 s, these craft centres have been acknowledged in various regions as the makers of carving. In its development, the government inaugurated this center in 2005. The centre's advantage lies in a variety of the relief carving models. This village produces relief carvings with various flora and fauna motifs and other motifs. Because of their advantages, the centres of carved furniture in Senenan have become carving barometer in Jepara. Many furniture entrepreneurs in Jepara order their furniture in Senenan carving craft centre [4]. Besides Senenan village, Mulyoharjo village is also a centre for making relief crafts. The presence of Jepara reliefs can have an impact on the socio-economic life of workers and craftsmen. The excellent skill in carving reliefs of craftsmen has enabled them to meet their economic needs. Starting from the background above, this article will explain the craft of relief carving and its impact on the economic life of $21^{\text {st }}$ century Jepara craftsmen.

\section{B. Method}

This research uses historical methods consisting of heuristics, criticism, interpretation, and historiography [5]. Heuristics that is performed is based on primary sources and secondary sources [6]. Primary sources were obtained from observation activities, government

* Corresponding author: alam_mahir@yahoo.com 
agencies and individuals in the form of statistical data, photographs of observations, and interviews with relief makers and craftsmen. Interviews were carried out on individuals involved in wood relief craft activities. Secondary sources were obtained from relevant works in the form of books, journals and other libraries. Secondary sources were obtained from libraries, private collections, or from browsing on the internet. Available sources were then criticized and interpreted. The results of the above analysis were then linked and reconstructed into an article about The Craft of Relief Carving Relief Art and Its Impact on the $21^{\text {st }}$ Century Jepara Craftsmen's Economic Life.

\section{Result and Discussion 1. Relief Carving Craft}

The craft of relief carvings found in Jepara reflects the influence of Hindu, Chinese and Arabic aesthetics. Hindu aesthetics are reflected in the Ramayana reliefs, Chinese and Arabic aesthetics reflected in the medallion and mega cloudy, and geometric or slimpetan [7] In its development, the craft of reliefs carving gained the influence of various ornamental varieties, including decorative, abstract styles and modern [8]. Relief carvings in the Hindu-Islamic transition period were found in Mantingan mosque foyer. It is known based on the medallion decorated with reliefs on both sides, on one of the sidesit was decorated with Ramayana reliefs, while the other side was decorated with new reliefs "Mantingan langgam" in the form of flora and fauna.In its development, many relief crafts were made by engravers and craftsmen reliefs with various types of original motifs from religious motifs, rural natural life, historical stories, Chinese reliefs, and other. The craft of relief carving is a carving product made with the aim to enjoy its beauty so that relief products are only used as display items. The craft of relief carving is included in the non-functional carving group. Non functional products that develop in Jepara is widely diverse and have various types. One of non-functional carving craft is relief [9].

\section{The Motifs of Relief Carving Craft}

The craft of relief carving is very diverse because it comes into contact with various fields in life, one of which is the religious field. In making reliefs, craftsmen get their inspiration from various religious events that are popular in the community. Relief art craft in Jepara comes into contact with Hinduism, Islam and Christianity, so the craft has a religious theme. This can be seen from the existence of the reliefs carving craft that depict the Ramayana story that is hunting, the events of the Christian Last Supper, and the mosque building.

In addition to religious themes, there are also reliefs with the theme of community life. Each relief has a philosophical meaning which describes a story. One of the life-themed reliefs illustrates the village atmosphere that is shady with the activities of farmers and cattle cart

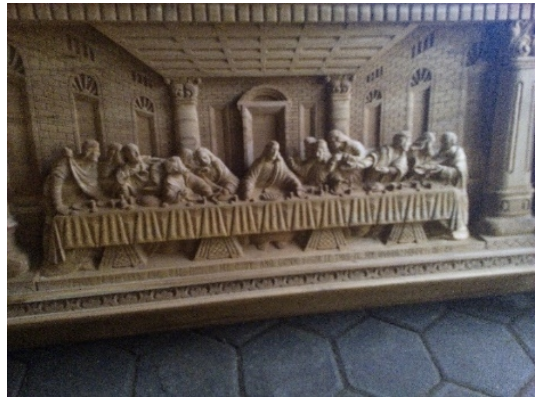

Figure 1. Relief of the Christian "The Last Supper"by Mulyoharjo Village Craftsmen. (Source. Author Documentation, 2017)

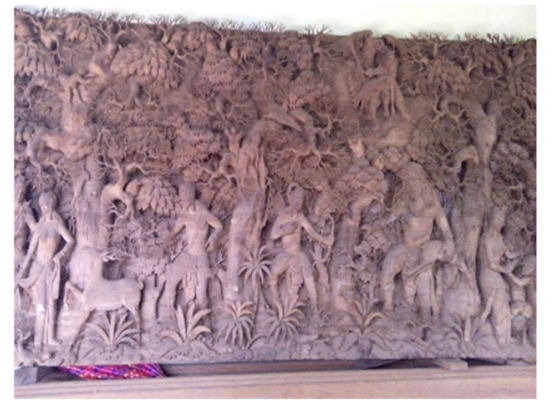

Figure 2. Carving Relief with the Story of Ramayana Hunting (Source. Collection of Teak Ega in Carved Relief Centre in Senenan documented by Author, 2017)

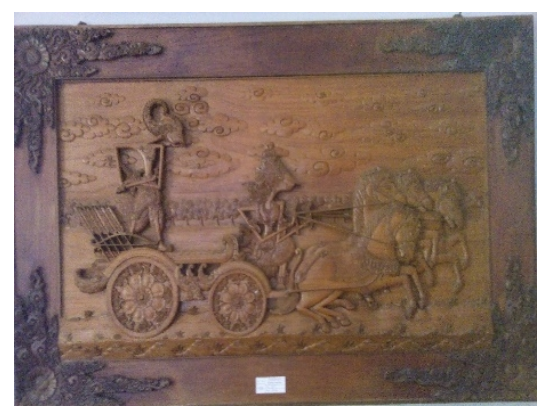

Figure 3. Carving Relief with Wayang Story as part of Jepara Carving Museum Collection (Source. Author Documentation, 2017)

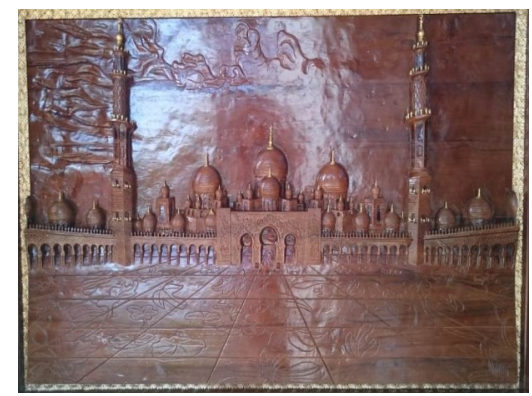

Figure 4. Carving Relief with Mosque Themes (Source.

Satria Collection Documented by the Author, 2018)

drivers. In addition, there are reliefs that have philosophical meanings including the relief of 8 horses. Relief of 8 horses has a meaning of great career, tenacity and courage, as well as the speed of action to achieve 
progress. There is also 9 koi relief which has a meaning of hope for prosperity and luck

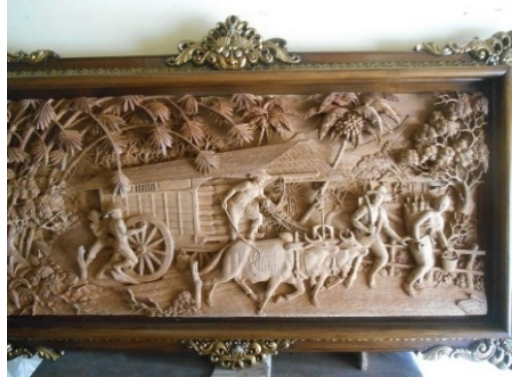

Figure 5. Cattle and Farmer Relief one of Soekarno's Works (Source: Soekarno's personal collection, documented by researchers, 2017)

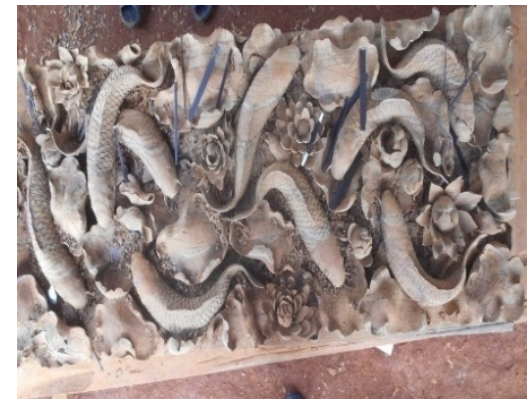

Figure 6. 9 Koi FishesCarving by Ali Rifa'I (Source. Author Documentation, 2017)

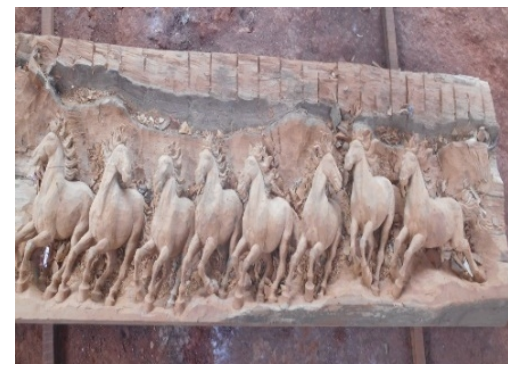

Figure 7. Relief of 8 Horses Running, by Ali Rifa'i (Source. Author Documentation, 2017)

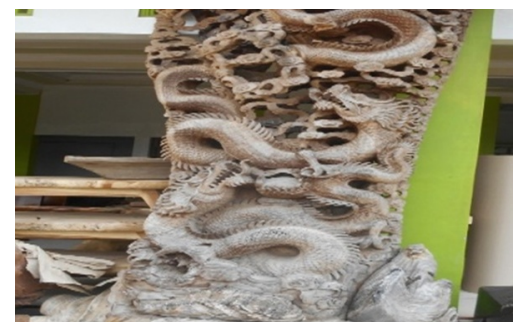

Figure 8. Relief Carving with Chinese Typical Motives from Mulvohario Village (Source. Author Documentation.

\section{Carvers and Relief Craftsmen}

According to Satria, the price of each relief depends on the complexity and the lack of relief motifs, the size of the relief, the type of the raw material, and the thickness of the raw material used. As an illustration, for the relief of the Abu Dabi mosque with 2 meters length and a 1.5 meters width using materials from Perhutani teak wood, it would require capital of 10 million rupiahs. The capital is used to buy teak wood for 3 million rupiahs, to pay the piece rate for about 4 million rupiahs for 1 month, to buy a frame worth 1 million rupiahs, and to pay the cost of finishing and refining for 3 million rupiahs. Of the 10 millions capital, if the relief is sold at the local market it would cost 15 million rupiahs and if it is sold abroad it would cost around 40 million rupiahs excluding shipping cost.

Slamet as the carver of relief carving makes reliefs depending on the order of the buyer or the order of the craftsmen. Relief prices are relatively expensive. Even reliefs that are large in size, the price of the relief frame reaches 5 million rupiahs. The finishing of the relief frame is either painted orprodo (made like a gold colour). Any themes vary depending on the demand of craftsmen or buyers who order. Rarely do engravers or craftsmen make relief carvings as stocks await for the buyers. They are worried about the large capital to make relief, not those who buy.

For reliefs with "abstract" motifs or themes, meaning has to be related with hell, which is depicted in relief with an image like desperate people. Relief prices for abstract motifs for the local market amounting to 12 million rupiahs include the price of the frame. The price is used for the cost of the frame making for 3 million rupiahs, the wages of wholesale workers for 4.5 million rupiahs, the price of raw materials for 1.8 million rupiahs, the finishing for 2 million rupiahs, and the rest are theprofits for the craftsmen. An "abstract" relief using $8 \mathrm{~cm}$ thick teak wood was done by one craftsman. They started working at 8:00 a.m. to 4:00 p.m. WIB. The manufacturing process takes about 2 weeks or 12 days

\section{The Impact on Economic Life}

The presence of relief carvings in several places in Jepara, both in Senenan Village and in Mulyoharjo contributed positively to carvers and craftsmen. The impact on the carver is that the soft skills possessed can be used to make a living and support the family. Currently (2018) in Jepara there is a scarcity of regeneration of relief carvers. The scarcity of skilled power of relief carvers makes the wages received rather high both daily and on a wholesale systems. The level of difficulty and complexity of carving wooden reliefs is quite high, not all carver can carve reliefs. It is estimated that on average, the wages received by the carver were around 75 thousand to 200 thousand rupiahs per day. With that amount of wage, they earn income to support their families.

The existence of relief carving crafts has a positive impact on the economic life of craftsmen. From the description of the price of relief carving products for local marketing, in about 2 weeks the average income is 1.5 rupiahs to 3 million rupiahs. For overseas marketing, the profit earned every month is around 5 million to 10 million rupiahs. The main skill of the craftsmen of relief that is needed is to build a marketing network for both domestic and foreign markets 


\section{Conclusion}

Carved Relief Art Crafts in Jepara existed around the 16th century which was marked by the discovery of ornamental reliefs from stone in the Mantingan Mosque. In its development, relief carvings experience ups and downs depending on market demand. At the beginning of the 21st century, the existence of carving craft was increasingly developed with the presence of the centres of the relief in Senenan Village and Mulyoharjo Jepara Village. In addition, this relief craft is supported by the existence of carving resources and the number of reservations. Relief motifs began to vary, including Ramayana, Agriculture or Rural motifs, Gajah Mada Stories, cross banquets, 9 dragons, mosques, and abstract motifs. The existence of this relief carving craft has a positive impact on engravers and relief craftsmen in Jepara. They can work as carvers and can market relief products both domestically and abroad.

\section{Acknowledgement}

The research is funded by DIPA Diponegoro University in 2018 budget year

\section{Reference}

1 Alamsyah, "The Ups and Downs of Wood Furniture Industry Center at the North Coast of
Java Before and After Reformation Era: The Case of Jepara Furniture Center", Advance Science Letters 201723 (10).

2 Badan Pusat Statistik. Statistik Kabupaten Jepara Dalam Angka Tahun 2017,

3 dikunjungi Senin, 1 Oktober 2018; https://id.wikipedia.org/wiki/Relief, dikunjungi Senin, 1 Oktober 2018;

4 https://peluangusaha. kontan.co.id/news/ sentramebel-ukir-jepara-jadi-barometer-1, "Sentra MebelJepara", dikunjungi Senin, 15 Oktober 2012 dan 22 September 2018))

5 Garraghan, Gilbert J. 1947. A guide to historical method. New York: Fordham University Press.

6 Herlina, Nina. 2008. MetodeSejarah. Bandung: Satya Historika.

7 Hayati, Chusnul, dkk, 2007,Ratu Kalinyamat: Biografi Tokoh Wanita Abad XVI dari Jepara, Semarang: Pemerintah Kabupaten Jepara dan Pusat Penelitian Sosial BudayaLemlit Undip bekerjasama dengan Penerbit Jeda; Maziyah, Alamsyah, Indrahti, 2015. Ornamen Mantingan. Semarang: Museum Ranggawarsita Jawa Tengah. 8 Kadir, Abdul, dkk. 1979. RisalahdanKumpula Data Tentang Perkembangan Seni Ukir Jepara. Jepara: Pemda Jepara; Wawancara dengan Slamet, Juli 2018.

9 Priyanto, Hadi, dkk., 2013. Mozaik Seni Ukir Jepara. Jepara: Lembaga Pelestari Seni Ukir, Batik, danTenun Jepara. 